Paideusis

\title{
Freire's Pedagogy of Freedom: Its Contribution to the Development of Ethical Teacher Professionality through the Implementation of the New Zealand Curriculum
}

\section{Leon Benadé}

Volume 19, Number 1, 2010

URI: https://id.erudit.org/iderudit/1072319ar

DOI: https://doi.org/10.7202/1072319ar

See table of contents

Publisher(s)

Canadian Philosophy of Education Society

ISSN

0838-4517 (print)

1916-0348 (digital)

Explore this journal

Cite this article

Benadé, L. (2010). Freire's Pedagogy of Freedom: Its Contribution to the Development of Ethical Teacher Professionality through the Implementation of the New Zealand Curriculum. Paideusis, 19(1), 5-15.

https://doi.org/10.7202/1072319ar

\section{Article abstract}

This paper takes lessons and directions from Paulo Freire's Pedagogy of Freedom (1998) that both inform the theme of Dialogue and Difference and a particular conception of ethical teacher professionality. Freire's vision of teachers and teaching challenges managerialist notions of teachers as dispassionate, data-driven objects of bureaucratic policy, aligned to a sanitised list of features that make up 'the effective teacher'. This representation of teachers is unlikely to motivate or prepare teachers in the future to be critical thinking ethical professionals.

An alternative conception of the teaching professional is required, and one is presented here which has strong links to Pedagogy of Freedom in particular, and critical pedagogy more generally. Expressed as 'ethical teacher professionality', this account suggests a broader approach to the role of teacher than provided by notions such as 'satisfactory teacher dimensions' or 'characteristics of quality teaching'.

The New Zealand Curriculum (Ministry of Education, 2007) is a policy text whose understanding of teachers is informed by such notions. New Zealand schools engaged in a process of preparation in 2008 and 2009 for full implementation of this revised national curriculum in 2010. The scope of these revisions, expectations of teachers, and the requirement that this implementation be school-based (rather than centrally prescribed) mean that in essence this curriculum goes well beyond a mere revision. Further, as a product of early-21st century education reform which seemingly gives schools, teachers and communities greater flexibility, there are lessons that could be relevant internationally. As a fundamentally new approach to policy, implementation of the New Zealand Curriculum could significantly alter how teachers see and approach their work.
This document is protected by copyright law. Use of the services of Erudit (including reproduction) is subject to its terms and conditions, which can be viewed online. 


\title{
Freire's Pedagogy of Freedom: Its Contribution to the Development of Ethical Teacher Professionality through the Implementation of the New Zealand Curriculum
}

\author{
LEON BENADÉ \\ University of Auckland, New Zealand
}

\begin{abstract}
This paper takes lessons and directions from Paulo Freire's Pedagogy of Freedom (1998) that both inform the theme of Dialogue and Difference and a particular conception of ethical teacher professionality. Freire's vision of teachers and teaching challenges managerialist notions of teachers as dispassionate, data-driven objects of bureaucratic policy, aligned to a sanitised list of features that make up 'the effective teacher'. This representation of teachers is unlikely to motivate or prepare teachers in the future to be critical thinking etbical professionals.

An alternative conception of the teaching professional is required, and one is presented here which has strong links to Pedagogy of Freedom in particular, and critical pedagogy more generally. Expressed as 'ethical teacher professionality', this account suggests a broader approach to the role of teacher than provided by notions such as 'satisfactory teacher dimensions' or 'characteristics of quality teaching'.

The New Zealand Curriculum (Ministry of Education, 2007) is a policy text whose understanding of teachers is informed by such notions. New Zealand schools engaged in a process of preparation in 2008 and 2009 for full implementation of this revised national curriculum in 2010. The scope of these revisions, expectations of teachers, and the requirement that this implementation be school-based (rather than centrally prescribed) mean that in essence this curriculum goes well beyond a mere revision. Further, as a product of early-21st century education reform which seemingly gives schools, teachers and communities greater flexibility, there are lessons that could be relevant internationally. As a fundamentally new approach to policy, implementation of the New Zealand Curriculum could significantly alter how teachers see and approach their work.
\end{abstract}

\section{Freirean Philosophy}

Freire would not have claimed to represent a philosophical 'tradition'. Nevertheless, his writing reveals several recognizable currents. The Catholicism of his childhood echoes throughout Pedagogy of Freedom. Of note is Freire's understanding of ethical behaviour in relation to the notion of transgression and regression (p. 25; p. 53; p. 92); his notion of coherence of words and deeds ("words not made flesh have little value", p. 39); the 'appropriate anger' education should foster against injustice, which Freire

(C) Copyright 2010. The author, Leon Benadé, assigns to Paideusis the right of first publication and educational and non-profit institutions a non-exclusive license to use this document for personal use and in courses of instruction provided that the article is used in full and this copyright statement is reproduced. Any other usage is probibited without the express permission of the author. 
likened to "Christ's anger against the merchants in the temple" (p. 45); the exercise of free will in "the right and the duty to opt" (p. 53) and his related rejection of predetermination and fatalism (p. 54); the theme of human 'unfinishedness' that permeates the work, and in response, the human desire for hope, which is "an ontological dimension of our human condition" (p. 58) and a denial of fatalism (p. 69); the demand of transformation to "announce a new utopia" (p. 74); Freire's 'I am a teacher' creed (pp. 9495), which rejects capitalism (p. 94); and finally his belief in teachers who make a difference by being a "committed presence in the world" (p. 110) and having an option for the poor (p. 122).

Hegelian and Marxist thinking shapes Freire's understanding of the dialectic - for instance, the interplay of theory and practice (although he made a point of giving practice precedence over theory, for example, p. 44 and p. 49); understanding a concept in light of its opposite, as already noted in terms of ethical behaviour; and in his use of dualisms (p. 88). Freire's reading of Marx influences his notion of oppressor and oppressed. Specific use of these terms in Pedagogy of Freedom is muted and appears instead in considerations of authoritarianism or limits to the development of student autonomy, such as efforts to stifle curiosity (pp. $79-80$ and pp. 95 - 99). In addition, Marxist thinking underpins Freire's belief in the conditioning (but not the determining) of people by their socio-historical reality (pp. $54-58$ ); that human beings are makers of history (p. 155); and of course his rejection of neoliberalism, capitalism, and globalisation (p. 22; p. 94; p. 114). Allied to these ideas was Freire's view that people are essentially 'unfinished' and in a state of 'becoming' critically conscious and able to transform their world (p. 66). There are, of course, other traditions that influenced Freire's thought, and these are thoroughly discussed in chapter 2 of Peter Roberts (2000) Education, Literacy, and Humanisation.

Freire's Pedagogy of Freedom is written from a 'progressive' point of view, which favours the autonomy of students as an aim of a critical and democratic education (p. 21). In neoliberalism and globalisation he saw a demand for the fatalistic acceptance of conditions encouraged by both. In particular, he had in mind global unemployment and partial employment (and the education that will prepare students for that status), the notion that there is an end to history and ideology, and the notion that education is neutral (and thus has no comment on these claims). Freire adds value to current educational debates because of his passionate rejection of neoliberalism and globalisation, which have helped to entrench a concept of teachers' work that is, in Freire's terms, 'dehumanising'. This is a concept that stifles a teacher's efforts to find personal critical autonomy, thus deadening the resolve of teachers to seek that status with students and for students. His humanistic discourse is a far cry from the demands for 'evidence-led teaching', 'teacher effectiveness', and 'school improvement'.

Freire regarded teachers as learners and learners as teachers in the dialectal search for knowledge and the development of critical thinking. Knowledge is not a consumer item and the student is not a 'client'. This search requires mutual respect for the freedom of the student and the authority of the teacher (pp. 95 - 99). The teacher's role is an ethical one committed to aiding students in their journey from what Freire calls 'ingenuous curiosity' to 'epistemological curiosity', which is rigorous, precise and critical (pp. 79 - 84). These observations and critiques are timelier than ever, adding significant value to educational debates that are incomplete without their insight. As will be suggested later, in the New Zealand context, where a clinical, dehumanising view of teachers' work holds sway, there is now an opportunity to challenge that view. In light of that possibility alone, Freire's philosophical orientation offers great value to debates about the role and preparation of teachers.

Despite Freire's understanding of difference, and his passion for students, teachers, and people in general as unique individuals coming from various points of difference, his thought has a universal quality, exemplified by his expression of a 'universal human ethic'. He argued vigorously that teachers (and teacher education) ought to be prepared for helping poor and marginalised students to develop their curiosity from a state of ingenuousness to a state of critical awareness and functioning. For Freire, the 'good life' is attained by all people becoming more fully human. Process rather than outcome is important, as a state of perpetual unfinishedness means that no-one could be fully human. Lifelong becoming means that people can only ever be more fully human (Roberts, 2000, p. 41) and it is the right of each person to seek to fulfill this ontological and historical vocation. 
As a cooperative enterprise between teacher and student, the attainment of this vocation is sought through critical dialogue and the development of curiosity. Aimed at helping students make practical and lived transformative changes in their own lives, this is a challenge that transcends difference. Despite his universal human ethic and belief that the goal of humanisation is prior to a belief that all ideas are equally relevant, Freire should not be considered absolutist (Roberts, p. 40). His commitment to cooperative knowledge construction and democratic dialogue ensures that the outcome is not always going to be the same. As noted above, process is more important, and it is this emphasis that challenges an education based on predictable outcomes.

Pedagogy of Freedom specifically challenges teacher education to be aware of the kinds of knowledge that should transcend difference because they are essential to all teachers. The first of these kinds is the knowledge of a pedagogy that will avoid the 'banking' transmission of content by focussing instead on creating the circumstances for knowledge construction (p. 30). A further sampling of challenges to teacher education programmes includes ensuring teachers have the knowledge to help their students move from a state of ingenuous curiosity to a rigorous and critical epistemological curiosity, whilst simultaneously developing affective intelligence (p. 48); developing in prospective teachers an understanding of human unfinishedness and the quest for hope (p. 58); and enabling teachers to cope with the tension between authority and freedom whilst rejecting authoritarianism and license (pp. 83-4). Less direct challenges to teacher education include the development of selfawareness in teachers of their role in a system that is never neutral and is subject to ideology. Underpinning all these challenges therefore is the need for teachers to be educated as ethical persons seeking the goals of humanisation and transformation for each student.

As this paper will go on to argue, a further challenge put before teacher education and educators is to participate and engage in the development of ethical professionals who are at once caring, thorough, and rigorous; and who are critical thinkers and public intellectuals dedicated to helping students develop a critical curiosity and capacity to change their world in fundamental ways. This development occurs in a context of and with the understanding that the ethical professional is never complete, and in that state of unfinishedness is constantly reminded to be humble, aware that backsliding, regression, and negation of the universal human ethic is an ever-present reality.

\section{Ethical Teacher Professionality}

Hoyle and John in their book, Professional knowledge and professional practice (1995), use the term 'professionality' "to refer to that set of knowledge, skills, values and behaviours which is exercised on behalf of clients" (p. 16). 'Professionality' is thus an organizational concept that elaborates what these writers consider to be the elements central to becoming a professional teacher, namely knowledge, autonomy and responsibility (p. 18). The term 'professionality' has been borrowed and adapted for use here in preference to 'teaching as a profession'. This use value is partly stylistic, but mainly is used because the clumsy 'teaching as a profession' suggests that whatever meaning may be ascribed to 'profession' is ascribed to its members by implication. 'Professionality' is both an identifier and a descriptor suggesting a sense of being reflecting an active commitment to what the concept entails, rather than a passive acceptance of being-ascribed-by. It thus anticipates the idea of a vocation, and also emphasises the references made to Freire's notion in Pedagogy of Freedom of the 'unfinishedness' of teachers (pp. 51-54). He notes that a teacher does not appear by accident, but exists by choice, exercising an option to intervene in an imperfect world to bring about transformative change. This change is never complete however, nor is the development of a teacher who, in this sense, is 'unfinished'. Professionality therefore suggests that the identity of a teaching professional is actively forged and developed by practice as a teacher.

Following Freire's argument that the 'ontological vocation' of people is to become more fully human (Freire, 1970, 1996, 1998), this paper proposes that teachers are called to take up an ontological 
vocation to become 'ethical professionals'. This ethical professionality is based on a specific sense of responsibility, articulated here as 'altruism', and considered to be a necessary feature of teaching as an ethical profession. Ethical teachers are called upon to reflect critically on their work and to use this critical and reflective attitude as a guide to developing their practice and continued reflections upon that practice (Freire, 1998, p. 30). This praxis strengthens, and is strengthened by, taking up critical pedagogy in daily teaching. This critical and reflective attitude also entitles, encourages, and calls upon the ethical teacher to speak out in various ways, demonstrating a willingness to be a public intellectual.

Freire links the teaching of content to the moral formation of students in Pedagogy of Freedom ( $\mathrm{p}$. 39) because "it is not possible to imagine the human condition disconnected from the ethical condition". For this reason provided by Freire, and for reasons such as the freedom to make conscious choices such as deciding to be a teacher, the role of the teacher is fundamentally an ethical one. The term 'professionality' is used in preference to 'teaching as a profession' which suggests that whatever meaning may be ascribed to 'profession' is ascribed to its members by implication. 'Professionality' suggests instead a sense of being that reflects an active commitment to what the concept entails, rather than a passive acceptance of being-ascribed-by. 'Professionality' also reflects the idea of a vocation, and emphasises the 'unfinishedness' of teachers (pp. 51 - 54). A teacher does not appear by accident, but exists by choice, exercising an option to intervene in an imperfect world to bring about transformative change. This change is never complete however, nor is the development of a teacher who, in this sense, is 'unfinished'. Professionality therefore suggests that the identity of a teaching professional is actively forged and developed by practice as a teacher.

Altruism as a necessary feature of teaching practice enables Freire's notion of the ethical teacher to be operationalised. Altruism is displayed by a commitment to 'the other', duty, and service. Commitment to 'the other' means acting out of caring concern for other people rather than out of concern for one's own interests or, for example, those of the Ministry of Education. Hoyle \& John (1995) suggest that 'responsibility' can bring teachers into conflict with 'accountability' when their commitment to students overrides their contractual obligations. However, if commitment to a student's perceived interests will result in unlawful acts or in some way compromise other ethical principles held by a teacher, then those interests will become secondary. ${ }^{1}$

Duty can be intrinsic (such as recognising the needs of a student who wants extra help to get better results and therefore making time available after school to help that student) or extrinsic (such as being in class when required to by the timetable, because that is what one is paid to do). In the former case, duty is an ethical concept and a legalistic one in the latter. Intrinsic acts are freely taken up by an agent, whereas extrinsic ones entail an obligation to duty by factors such as a salary reward. Frankena (1973) notes that obligation carries the corollary of rights. If a teacher is obliged by contract to teach, this is because the student is entitled, by right, to be taught. The same student cannot, however, expect as of right that a teacher will voluntarily give up time after school to help that student. That a teacher does so is an act of altruism. ${ }^{2}$

The idea of 'service' conveys the idea that one is working for others and in their interests, placing these above or beyond one's own. Moreover, it carries the idea that this work is carried out for reasons other than extrinsic, material ones (Wise, 2005). This idea of 'service' is sometimes conceptualised as 'social responsibility' (Brien, 1998). This sense of 'mission' is a necessary component of the altruism that characterises an ethical teacher. Such teachers are motivated by a belief in the goodness of people and their ability to enhance that goodness by 'making a difference'.

\footnotetext{
${ }^{1}$ Note in this regard Snook, who considers the right of the teacher to reveal confidences about a student if it meant maintaining the confidence would endanger the life or safety of the student (Snook, 2003).

${ }^{2}$ Freire also drew attention to the relationship of rights to duties when he suggested that in order to fulfil their duties to teach, it is necessary that teachers provide a safe learning environment, failure to do so being an "offence to learners" (p. 64).
} 
These characteristics of altruism are not necessary to teaching per se. It is likely that there are people in teaching who have a low opinion of their students and of the world in general and who do not believe that their effort will make one iota of difference to the lives of anyone. Such people however, could not on the account given here, nor on Freire's account, be considered as ethical teachers. On his account, teachers who choose not to engage in their world are passing by the opportunity to excel as ethical professionals. They could excel as teachers who are performing a competent technical job, but they may be caught up in a form of oppression of which they are not aware, that will render their work as less ethical. As indicated earlier, Freire (1998) explains an ethical disposition by virtue of the disposition to choose to be unethical (p. 25; p. 53; p. 92). Although ignorance is not a defence against the charge of culpability, the person who merely exists or operates as an object rather than as a critical subject may not be choosing to be unethical; that person may simply be unaware that such a distinction even exists.

The account given of a practice of altruism based on an orientation to the other, duty, and service is problematic, however. The idea that one may selflessly commit to serving others at no reward at all seems implausible, thus suggesting that altruism is implausible, because an agent will always be motivated by self interest. This is however a narrow definition that considers the motivation to acts of altruism to be the happiness of others, requiring the happiness of the agent to be subordinated to that of the other. Broadly defined, however, there should be no expectation that even the most selfless teacher would entirely diminish so another can increase, nor should there be any obligation on a teacher to do so. This understanding echoes Freire's view that the disposition to humility on the part of the ethical teacher is not an act of submission (p. 109).

Broadly understood, teachers acting altruistically do derive rewards, such as professional satisfaction or seeing their students achieve. A narrow definition will consider that altruism is possible only when complete strangers perform uninitiated, random, and unique acts of kindness to other strangers with no likelihood of reward (Quigley, Gaes, \& Tedeschi, 2001). This narrow account fails to acknowledge that many teachers undertake beneficent works on behalf of, or as a service to, students they know-students whom teachers know to have expressed needs-with little or no expectation of reward other than the satisfaction of meeting those needs. The broad conception of altruism proposed here motivates everyday acts based on what Strike (2000) calls moral conceptions of kindness and decency that are extended to people with whom one has a certain affinity. The tenor of Freire's account of an ethical teacher in Pedagogy of Freedom suggests that he would concur with the broad understanding of altruism given here.

The confines of this paper prevent a full development of altruism, so it must suffice to pose some questions. Does commitment to altruism presuppose that the teaching profession consists of those who are ethical and those who are not? To clarify: in essence teaching is an ethical activity, thus inviting all teachers to take up an ethical position (that is, fulfilling an ontological vocation to be ethical professionals). Similarly, Freire's view was that teaching is 'profoundly formational and thus ethical' (p. 63), and teachers are ethical by virtue of (amongst other characteristics) their decision to opt to teach and make a difference. Does this mean Freire's view was that all teachers are ethical professionals? The answer is negative, because despite his optimism, Freire's acknowledgement of the freedom to opt was also an acknowledgement of the freedom not to opt, and as noted, he made frequent reference to forming ethical understanding by recognising transgression. Therefore, Freire recognised that teachers will leave a mark on the classroom and students regardless of what kind of person or teacher they are (p. 64).

One way of freely and consciously taking up an ontological vocation to become an ethical teaching professional is to commit to a critical pedagogy. Critical pedagogy calls on teachers to "develop pedagogical theories \& methods that link self-reflection and understanding with a commitment to change the nature of the larger society" (Giroux, 1997, p. 28). Critical pedagogy is therefore concerned with more than simply methods of teaching; it is concerned with developing a holistic approach to teachers' work that requires teachers to consider the impact of their teaching not 
only in the classroom but beyond it. In Pedagogy of Freedom (p. 32; pp. 66-7) and elsewhere (Freire, 1970), Freire actively rejected 'banking education', condemning a transmission style of teaching in favour of dialogical 'problem-posing' education that would develop critical epistemological curiosity. A dialogical method (pp. 79 - 84; p. 105), based on an evolving dialogue between students and teacher, enables both to explore what they know and what they do not know; (Shor \& Freire, 1987, p. 99). A pedagogy that is problem-posing calls on the teacher to treat the student's life experience and prior knowledge as text, using this text as an authentic context for learning.

This pedagogical approach requires that the teacher take up a particular position requiring a constant process of critical self-reflection and a commitment to students 'recreating and remaking' knowledge (1998, p. 31). Because it is an approach that takes student experience, values, and concerns as a text, it breaks with recitation and allows students to speak their own histories (Giroux, 1997). This suggests therefore that critical pedagogy is a pedagogy of difference rather than a universalist pedagogy. Despite elements of universal theorising in Pedagogy of Freedom, Freire was strongly committed to critical pedagogy. Indeed, he saw this pedagogy, with its emphasis on dialogue and critical questioning, leading the learner from ingenuous curiosity to a critical epistemological curiosity, as a way to break the oppressor-oppressed relationship.

This brief rendition of critical pedagogy highlights the tension in Pedagogy of Freedom (and no doubt in many other Freirean texts) between a universal world and one of difference. On one hand is a tension between a universal human ethic and recognition of the oppressor-oppressed relationship. On the other is recognition of each student's life as a valid and unique text whose critical appreciation will help each student's quest for freedom. ${ }^{3}$ This rendition of critical pedagogy also overlooks the enormous development of critical pedagogy by other writers, and the critiques of critical pedagogy. See, for example, chapter six of Nash (1997). This is not the place to analyse or even paraphrase these various streams of thought, suffice it to say, from Freire's perspective, but an ethical teacher understands there is no teaching without learning, accepts that teaching is not just transferring knowledge, and affirms that teaching is a human act (Pedagogy of Freedom, Contents, pp vii-viii).

The last of these points allows some concluding comments about ethical teacher professionality. As noted previously, teachers are more than just persons who appear before students in a classroom; they are influential in a mutual process of formation. They assist students in engaging in a process of developing critical curiosity; and because teachers see themselves as learners, they too are formed by this experience. Their role of formation extends to assisting their students to take up their rights and obligations as citizens of a democratic state. Accordingly, teachers must model and display those characteristics. Teachers therefore have a duty, as one of their democratic obligations, to be informed by wider public debate and to inform those debates with their own critical and considered views. Giroux argued that teachers identify themselves as transformative intellectuals who occupy specific socio-cultural spaces, thus resisting narrow definitions as 'professionals'. He called on teachers to become public intellectuals capable of taking a position on local, regional, national, and international issues $(1997$, p. 224). Freire insisted that teachers failed their task if they did not "express appropriate anger against injustice, against disloyalty, against the negation of love, against exploitation" (1998, p. 45). Later, he claimed that it "is not by resignation but by a capacity for indignation in the face of injustice that we are affirmed" (p. 74). However it is not enough to denounce: transformation demands the need to "announce a new utopia" (p. 74). Throughout Pedagogy of Freedom runs the theme that teachers consciously opt to make a difference, and that they do so in a powerfully public forum.

Freire's vision of teachers and teaching challenges managerialist notions of teachers as dispassionate, data-driven objects of bureaucratic policy, aligned to a sanitised list of features that make up 'the effective teacher'. Such notions seem to echo in the pages of a recently mandated national

\footnotetext{
${ }^{3}$ Freire's own position on post modern difference was complex (Roberts pp. 111-116) and perhaps eclectic, seeking to incorporate its positives whilst rejecting its negatives.
} 
curriculum for New Zealand. However, the New Zealand Curriculum (Ministry of Education, 2007) has an essentially contradictory nature which offers teachers an opportunity to challenge those notions. It is to a brief consideration of this idea that this paper will now turn.

\section{Implications for Ethical Teacher Professionality of the 2007 New Zealand Curriculum}

Following a review and revision by the New Zealand Ministry of Education of the previous Curriculum Framework between 2000 and 2006, the New Zealand Curriculum (2007) was released to New Zealand schools late 2007. This national curriculum applies to all schools, from Year 1 to Year 13, and contributes to the development of a seamless education that links with the Early Childhood and Tertiary sectors. "Its principal function is to set the direction for student learning and to provide guidance for schools as they design and review their curriculum" (p. 6). The New Zealand compulsory education system (some 2500 schools) functions as a single jurisdiction on behalf of which the Ministry of Education shapes and directs policy. Each school is self-governing, being managed by a parentelected Board of Trustees which is turn are subject to a range of legislation. By and large, all schools are owned by the Crown, although the system includes state-integrated (mainly Catholic and Christian) schools, which are partly privately owned, and full private schools. All schools are registered and must therefore offer the national curriculum. The revised curriculum was gazetted for official use and implementation by February 2010.

The New Zealand Curriculum has expectations of teachers and schools that could significantly alter how teachers see and approach their work. Consequently, there are challenges and invitations to teachers and teacher education to seize the opportunities for ethical professionality presented by the Curriculum. Given space limitations, the present purpose is limited to one significant expectation of teachers, namely that they develop reflective, critical, and metacognitive thinking in their students. This expectation is referred to throughout the Curriculum, some examples of which are outlined in the extracts that follow.

\section{Principles}

This foundational aspect of the Curriculum notes that "... principles relate to how curriculum is formalised in a school [and] are particularly relevant to... planning, prioritising and review" (2007, p. 9). Furthermore, principles "... embody beliefs about what is important and desirable in school curriculum..." (2007, p. 9). These principles include a belief in 'learning to learn': "The curriculum encourages all students to reflect on their own learning processes and to learn how to learn" (2007, p. $9)$.

\section{Values}

Critical and reflective thinking is regarded here as a tool or device by the use of which students will come to 'value' innovation, inquiry, and curiosity (2007, p. 10).

\section{Key Competency: Thinking}

The use of critical and metacognitive processes defines thinking (instrumentally) as " $\ldots$ developing understanding, making decisions, shaping actions, or constructing knowledge" (2007, p. 12). A thinker is self reflective, makes connections, and can question and challenge assumptions (2007, p. 12).

\section{Technology}

'Informed critical and creative thinking' produces 'quality outcomes' in Technology. Students are also required to "... consider ethics... and potential impacts [of Technological Practice] on stakeholders and 
the environment" (2007, p. 32), which may be presumed to require a high degree of reflective and critical thinking. Critical thinking is the outcome or product of learning that requires students to "... learn to critique the impact of technology on societies..." (2007, p. 32).

Although some of these extracts reveal an instrumental understanding of 'thinking' and an absence of political or ethical perspective, seen from the Freirean perspective of teachers fulfilling an ontological vocation as ethical professionals, they could suggest important first steps to conscientisation. The implementation of the Curriculum at a local level has great potential for notions of both difference and dialogue. Difference is encouraged by an implementation process that invites school communities to interpret and implement the curriculum at their level. However, implementation depends heavily on the values or priorities of those with power at the local level, especially principals and school senior managers. These are the people who will direct implementation, although it is largely teachers who help to shape the form and content of implementation. Therefore, dialogue is a further strength of this curriculum policy, requiring the voices of teachers, students, and the community to be heard, as implementation is negotiated. The implementation of metacognition could for example invite dialogue and debate over whether reflective and critical thinking is merely an aspect of metacognition or if it is seen as a precursor to conscientisation. This is a challenge to teacher education programmes to assist new teachers to grapple with these distinctions. Not only does such philosophical work help make sense of a complex policy text, it also facilitates the development of sound argument and rational thought within the staffroom discussions and teacher workshops that will continue to shape the implementation of the New Zealand Curriculum in each school. How does the curriculum shape such opportunities for dialogue and a consequent challenge to teacher education? This question is answered by further reference to the New Zealand Curriculum.

\section{Effective Pedagogy}

In this section of the document, teachers are directed to teach students to be reflective and to learn attributes of objectivity, critique, and metacognivity. Although teachers are acknowledged as learners (2007, p. 34), it is only the 'reflective discourse' students have with others that is noted as significant. Where 'critical thinking' may apply to teachers is in regard to 'teaching as inquiry' which calls on teachers to "... inquire into the impact of their teaching on their students" (2007, p. 35). However this 'impact' has nothing to do with ethics or politics or wider socio-economic significance, but is simply a focus on the content, method, and assessment that will continue to guide good teaching practice (2007, p. 35).

Whilst it is naïve to assume that teachers should not, as a priority, consider the effects of their teaching, it is unlikely that many teachers can concentrate only on their teaching. Some may wish that they could concentrate just on that aspect of their work; the reality for many teachers is quite different. Their work, just like the lives of their students, is located in a complex context of socio-economic and political realities, where for many students just getting to school is a challenge, let alone getting to school having had breakfast; a context in which nearly $11 \%$ of students countrywide have been truant at some stage during the year (New Zealand Ministry of Education, 2006); a context in which schools have had to become 'full service' facilities, including providing on-site health and social support services (Achievement in Multi Cultural High Schools, 2008); and a context in which secondary teachers are teaching in classes where on average no student can expect more than four minutes of a teacher's time in a period (New Zealand Post Primary Teachers' Association, 2008). The calls for improved teaching to deliver improved learning outcomes through such processes as metacognition come at an enormous price for teachers attempting to create the circumstances and context in which students can be 'made ready' for learning before any teaching can begin; calls which Thrupp, in an address to the NZPPTA, suggests can be traced back to the 'lingering politics of blame' (Thrupp, 2008) in New Zealand education.

Despite this pessimism, Freire's call to avoid the fatalism encouraged by neoliberal economic policy on ordinary people and different communities is uplifting, and so the opportunity (no matter 
how dimly stated) for teachers to engage in critical self-reflection and dialogue must be grasped. The model of 'teaching as inquiry' (New Zealand Curriculum, p. 35), whilst seemingly restricted to inquiring more deeply into the implications of teaching and likely future steps to further engage students in learning, provides the potential to develop a Freirean model of praxis.

This is a model that reflects Freire's philosophy of a problem-posing education that is for freedom rather than economic utility, in which the teacher is a learner, respecting the knowledge the learner already has. It is a model that encourages teacher reflection on action, with consequent changes or adaptations to that practice. Freire's view, expressed several times in Pedagogy of Freedom, is that action has primacy over theory; that a teacher's theoretical position should be one of critical openness to change and new ideas; and that a teacher must strive for a coherence of theory and practice, of words and deeds (pp. 39-40; p. 63; p. 49; p. 88). Freire's theory of teaching and learning is one in which the

essential moment is that of critical reflection on one's practice. Thinking critically about practice, of today or yesterday, makes possible the improvement of tomorrow's practice. Even theoretical discourse itself, necessary as it is to critical reflection, must be concrete enough to be clearly identifiable with practice. (pp. 43-44)

His strategy follows the steps of: problem identification; problem analysis; creation of a plan of action to address the problem; implementation of the plan; analysis and evaluation of the action (DuncanAndrade \& Morrell, 2008, p. 25). This model both problematises teaching and learning, whilst achieving Freire's goal of moving toward the liberation offered by attaining critical epistemological curiosity. In contrast, the model of 'teaching as inquiry' in the New Zealand Curriculum (p. 35) limits itself to asking: What is important given where my students are at? What strategies (evidence-based) are most likely to help my students learn this? What happened as a result of the teaching, and what are the implications for future teaching? This model is narrow and limiting, yet its very existence implies the opportunity for teachers to expand their horizons in the way intended by Freire, thereby going significantly further, and in the process, deepening their ethical engagement with the education process.

\section{Conclusion}

It is expected that implementation of the New Zealand Curriculum by schools shows their commitment to reflective and critical thinking and metacognition. Although actual implementation will vary according to interpretation and taste for change at the local school level, these priorities play a significant role in the discourse of curriculum implementation. It is significant that several references in the curriculum (including some mentioned earlier) suggest that students will be required to attain ethical intelligence and develop skills of socio-economic, political, and cultural critique. This opens the door to the deeper engagement Freire had in mind with the consequent potential to develop ethical teacher professionality.

Freire's philosophical approach expressed in Pedagogy of Freedom by no means represents the fullness of his wide-ranging thought and work. However, it poses several intriguing possibilities and certainly opens up an interesting line of debate. It would have been in Freirean style to prefer dialogue, as it is through a dialogical and problem-posing process that knowledge is apprehended, understood, recreated. The New Zealand Curriculum provides an opportunity for communities of teachers, students and families to develop their unique difference and representation as communities. For teachers and teacher educators, Freire's challenge is to develop as ethical professionals such as has been suggested here. 


\section{Acknowledgments}

This paper was presented at the 38th Annual Meeting of the Philosophy of Education Society of Australasia (PESA), held from December 3 to Sunday, December 6, 2009, at the East-West Center in Honolulu, Hawaii.

\section{References}

Achievement in Multi Cultural High Schools. (2008). Retrieved 18 May 2008, from http://www. aimhi.ac.nz/default.asp

Brien, A. (1998). Professional ethics and the culture of trust. Journal of Business Ethics, 17(4), 391-410.

Duncan-Andrade, J., \& Morrell, E. (2008). The art of critical pedagogy: Possibilities for moving from theory to practice in urban schools. New York: Peter Lang.

Freire, P. (1970). Pedagogy of the oppressed. London: Penguin.

Freire, P. (1996). Letters to Cristina (D. Macedo, Trans.). New York: Routledge.

Freire, P. (1998). Pedagogy of freedom: Ethics, democracy and civic courage. Lanham, Maryland: Rowman and Littlefield.

Giroux, H. (1997). Pedagogy and the politics of hope: Theory, culture and schooling. Boulder, Colorado: Westview Press.

Ministry of Education. (2007). The New Zealand Curriculum. Wellington: Learning Media Limited.

Nash, R. (1997). Answering the 'Virtuecrats': A moral conversation on character education. New York: Teachers College Press.

New Zealand Ministry of Education. (2006). Truancy from school. Retrieved 18 May 2008, from http://www.educationcounts.govt.nz/statistics/data_cubes/student_participation/schooling/tr uancy_from_school

New Zealand Post Primary Teachers' Association. (2008). Why class size matters. Retrieved 18 May 2008, from http://www.ppta.org.nz/internal.asp?CategoryID=100005\&SubCatID=100587\& SubCat1ID $=100648$

Quigley, B., Gaes, G., \& Tedeschi, J. (2001). Does asking make a difference? Effects of initiator, possible gain, and risk on attributed altruism. The Journal of Social Psychology, 129(2), 259-267.

Roberts, P. (2000). Education, literacy, and humanisation: Exploring the work of Paulo Freire. Westport, CT: Bergin \& Garvey.

Shor, I., \& Freire, P. (1987). A pedagogy for liberation: Dialogues on transforming education. Westport, CT: Bergin \& Harvey.

Snook, I. (2003). The ethical teacher. Palmerston North, NZ: Dunmore Press.

Strike, K. (2000). Liberalism, communitarianism, and the space between: In praise of kindness, Journal of Moral Education 29(2), 133-147.

Thrupp, M. (2008). Teachers shouldn't be blamed for wider social problems. Retrieved 18 May 2008, from www.ppta.org.nz/internal.asp?CategoryID $=100006 \&$ SubCatID $=100646$ \#teacherblame

Wise, A. (2005). Establishing teaching as a profession. Journal of Teacher Education, 56(4), 318-331.

\section{About the Author}

Leon Benadé is a doctoral candidate in the School of Critical Studies in Education of the Faculty of Education, University of Auckland. He has had a career in secondary schools in South Africa and New Zealand in positions as teacher, middle manager, and senior leader. More recently, he has worked as an independent consultant to schools and Boards of Trustees. His research interests include teachers' 
work, professionalism, the ethics of teachers' work, and the impact of education policy on schools and teachers. He has a special interest in the application of Freirean ideas to education. Email: benade@xtra.co.nz 